AÜIFD Cilt XLIII (2002) Sayı 2 s. 497-503

\title{
Kitap Tanitma
}

\author{
Ar. Gör. Fatih ERKOÇOĞLU
}

Bandırmalızâde Mehmed Muhsin, Afrika Delili, el-Fellâh Cerîdesi Matbaası, Kahire 1312/1894.

Ưmmü'd-Dünya diye anılan Mısır, Nil Nehri'nin varlı̆̆ı ile elde ettiği zenginlik sayesinde cazibe bölgesi hâline gelmiş ve birçok fatihin uğrak yeri olmuştur. Nil Nehri bölgede Mısır Medeniyeti olarak adlandırılan büyük bir medeniyetin oluşmasında katkı sağlamıştır. Dünya harikalarından sayılan piramitler de yine burada inşa edilmiştir. Tarihî, sosyal ve kültürel zenginliği nedeniyle Mısır hakkında birçok eser telif edilmiştir. Bu eserlerden birisi de Bandırmalızâde Mehmed Muhsin Bey (ö.1906)'in h. 1312 yılında el-Fellâh Ceridesi Matbaası'nda basılan Afrika Delîli isimli eseridir.

Eserin yazanı Bandırmalızâde Mehmed Muhsin Bey hakkında Bursalı Mehmed Tahir, Osmanlı Müellifleri adlı eserinde (c.III, 104, 105) "tahsili sonrasında Osmanlı Devleti'nin Mısır Fevkalâde Komiseri Gazi Ahmed Muhtar Paşa'nın maiyetinde birinci katiplik (eserin başında ikinci katip olarak ifade ediliyor) hizmetinde müteakiben de Istanbul'a nakledilerek Tevki-yi Divân-ı Hümâyûn memuriyetinde daha sonra da Şurâ-yı Devlet azalığında bulunmuştur. 1906 yılında vefat ederek Úsküdar'da İnâdiye Mahallesi'nde dedesinin yaptırdığı Bandırmalızâde Dergâhı ismiyle anılan Celvetî Dergâhı'na defnedildiği" şeklinde bahsetmektedir.

Eserin girişinde Mısır Fevkalâde Komiseri Gazi Ahmed Muhtar Paşa, tarih ilminin ve eski toplulukların âdet, ahlâk ve hadiselerinin bilinmesinin öneminden bahsettiği bir takriz yazmıştır ( 9 Receb 1314/1896). 
Eser Mukaddime (s.3-7), Medhal (s.8-116), Mebhas (s.117-231), Zeyl-i Mebhas (s.232-303), Lâhikâ-i Mebhas (304-371), Tetimme (s. 372-769) kısımlarından oluşmaktadır. 769. sayfada birinci cildin sonu ifadesinin düşülmesi ikinci ya da başka ciltlerin varlığını düşündürmektedir. Birinci cildin sonunda müellif, Napolyon'un Mısır'ı işgaliyle birlikte cereyan eden olayların ikinci ciltte ele alınacağından bahsetmektedir. Bu durumda basılmaya hazır bir cildin bulunduğu düşünülebilir. Ancak yaptığımız kısmî araştırmalarda ikinci ya da diğer ciltlerle ilgili bilgilere rastlayamadık.

Mukaddime kısmında müellif, öncelikle Sultan II. Abdülhamit Han'a ve Gazi Ahmed Muhtar Paşa'ya övgüyle başlamakta müteakiben de tarih ve coğrafya ilminin ehemmiyetinden, Habeş ve Yemen muhaceretlerini örnek vermek suretiyle faydasından bahsetmektedir. Tarih ilminin önemini ise "cihân-ı marifette tarih gibi bir hâce-i infân tasavvur olunamaz" demek suretiyle vurgulamaktadır (s. 4). Sonrasında "Binâen aleyh mâziyi hâle ve hâli istikbâle tahvil-i kudret hükmiyyesi îcâbından olan fenn-i tarihe yalnız me'add-ı manevî değil zübde-i dekâyık-ı hâdisât ve rûznâme-i kadem ve'l-hâstl mürşid-i şâh-râh-t ümem denilse bile câmi' olduğu mahiyyyet-i "ulviyyeye göre hakklyla ser-nâme-i i'zâz ve evsâfi olamaz" diye devam etmektedir (s. 4). Tarih ilmine intisabın sadece olayların ve bu olaylarla ilgili isimlerin, yerlerin ezberlenmesi, bunların da nakledilmesinden ibaret olmadığını gerçek maksadın tarihi hikmet noktasında ferdin uyanıklık durumunu elde etmesi olarak veren müellif, yaratıldığı yer olan dünyasını tanımayan insanın çocuktan, coğrafya bilmeyen tarih ya da hikmet-i siyasiye öğretmeninin cahil eğitimciden ne farkı olabilir? demek suretiyle tarihe verdiği önemi göstermektedir (s. 5). Daha sonra sözlerine devamla "...malının nerede rağbet göreceğinden haberi olmayan tacirin kazanct pişmanlık, askerî harekat yapılacak bölgenin tabii ve coğrafi durumunu bilmeyen bir komutanın da bütün gayretlerinin mağlubiyet olacă̆ından" bahsetmektedir. Tarihi bilmenin önemi hakkında bu ifadelere yer verdikten sonra yazar, Osmanlı Devleti'nin bir parçası olan Mısır ile ilgili olarak -(kendi ifadesiyle) her ne kadar Fransızların hazırladıklan çalışma kadar olmasa da ve Mısır'la ilgili yapılmış Türkçe bir eserin dahi bulunmaması nedeniyle- böyle bir çalışmaya başladığını belirtmektedir.

Medhal kısmında (s.8-116) müellif Afrika'nın tabi-i durumunu, yüzölçümünü, sahillerini, burunlanın, adalanın, dağlarını, birinci derecede nehirlerini (Nil, Nijer, Kongo, Zanbaze), ikinci derecede nehirlerini (Senegal, Ğanzâ, Oranj, Limpopo, Ruvuma), meşhur göllerini (Akhajar, Çad, Niğâmî, Büyük Uğanda, (Niyanza), Tanganika, Niyassa, Çad, Küçük Uğanda (Albert Niyanza), Bangveulu, İstefani), Afrika'nın hava durumunu (iklimi), maden 
serveti, bitkileri, hayvanları, halkı, dilleri, dinleri, geçim şekilleri, sanayini, ticaretini, yollar ve geçitlerini, medeniyetini, siyasî dağılımını konu edinmekte ve sonrasında belli başlı ülkeleri başlıklar halinde ele almaktadır. Burada yer verdiği ülkeler şunlardır; Fas-Marakeş, Cezâyir, Tunus Eyaleti, Trablusgarb, Binğâzi Mutasarrifiyeti, Sahrâ-yı Kebîr, Habeşistan, Zengibâr, Senegâl, Madagaskar, Sudan-ı Merkezi, Afrika'nın Batı Sahilleri, Doğu Gine (veya Yukarı Gine), Adalar (Madeira Adaları, Kanarya Adaları, Yeşil Burun Adaları, Fernandopo Adası, Prens Adası, Saint Thoma Adası, Assension Adası, Saint Helen Adası), Doğu Sudan, Uğanda, Unyuru, Ğallilâs İklimi, Doğu Afrika, Mozambik, Matabilla, Zulustan, Natal, Oranj Cumhuriyeti, Transval, Kap Sömürgesi-Ümid Burnu, Güneybatı Afrika, Angola, Kongo. Müellif burada zikrettiğimiz ülkelerin genel olarak coğrafì konumları, yeryüzü şekilleri, sınırları, nüfusları, nüfus dağılımları, tarihleri, iklimleri, ticaretleri, mahsulleri, idarî bölünüşleri, silahlı kuvvetleri, eğitim kurumları o ülkelere mahsus bir kısım özelliklerini kısa ve özlü bir şekilde vermektedir.

Mebhas (s.117-231) başlıklı ikinci kısımda ise yazar Mısır hakkında teferruatlı bilgilere yer ayırmıştır. Mısır'ın ayrıntılı bir şekilde ele alındığı bu kısımda coğrafî konumu, tarihî, idarî bölümlenmesi verildikten sonra Kahire şehrininin genel durumunu ve tarihini anlatmaktadır. Müteakiben de sırasıyla Kalyûbiyye Müdüriyeti (Livâ) (şehir, mahsulatı, meşhur ve önemli noktalar, eski eserleri, burada doğan meşhur kimseler), Kanâtır-1 Hayriyye, Şarkiye Müdüriyeti, Tel Kebir, Dekahliye Müdüriyeti, Mansûra, Menûfiye Müdüriyeti, Ğarbiyye Müdüriyeti, Buheyrâ Müdüriyeti, Mısr-ı Ulyâ (Vech-i Kıbelî), Cîze Müdüriyeti, Eski Mısır (veya Fustat), Cîze Heremleri (Piramitler), Ravza Adası (yahut Menyel), Mikyâs-ı Nîl (Nilometre), Nil'in kaynakları, Meşhur Kanallar, Kadim Mısır Toplumu, Menfis Şehri, Benî Süveyf Müdüriyeti, Feyyûm Müdüriyeti, Bahr-i Yûsuf, Liberant, Minye Müdüriyeti, Asyût Müdüriyeti, Circâ Müdüriyeti, Kinâ Müdüriyeti, Kûs Müdüriyeti, Luksor, Karnak, Kûrna, bû, Ferşût, İsnâ Müdüriyeti, el-Kusur, İsnâ Şehri, Armant, Mata'ına, Idfû, Asvân, Ebû Sinbel, Cezîret-i Berbâ, Port Saîd Muhafızlığı, Kanal Muhafızlığı (Süveyş), Fermâ, Ismailiyye, Arîş, Kusayr, Süveyş Kanalı, Savakin Muhafızlığı, Tavkar, Sinkat, Masu' Muhafızlığı, Zeyle', Berbera Limanı, Dimyât Muhafızlığı, Reşîd Muhafızlığı, İskenderiye Muhafızlığı (coğrafî konumu, tarihi, Napolyon Bonapart'ın asker sevkiyatı ve savaşları tarihi) başlıkları ve özellikle muhafızlık ve müdüriyet isimlerinin geçtiği yerlerde o yerin tarihi, coğrafyası, eski eserleri ve meşhur kimseleri hakkında teferruatlı bilgileri vermektedir. 
Müellif Zeyl-i Mebhas kısmında (s.232-303) belirttiği gibi yukarıda zikrettiği başlıklar altında incelediği bilgilerin yeterli olmadığını ve diğer konu ve bilgileri İstitrâd başlığı altında ele aldığını ifade etmektedir. Bu kısımda Vahalar, Göller, Dağlar, Madenler, Mısır'ın Havası, Ağaçları, Hayvanlan, Ziraat, Sanayii, Mahsulâtı, Gümrük ve Ticâret, Arazi, Ziraat, Maarif, Demiryolları, Telgraf Hatlan, Posta başlıkları inceleniyor.

Gümrük ve Ticâret başlığı altında ithal ve ihraç olunan eşyanın iki senelik (1890 ve 1891) cinsi, miktarı, farkı ve alınan vergi şeması verilmektedir. Yine burada bir şema halinde bu yıllarda ihraç edilen pamuk, pamuk tohumu, bakla, Mısır buğdayı, buğday, arpa, pirinç, şeker ürünlerinin kantar hesabıyla miktarı, tütün, tönbeki ve yaprak sigarası kilogramı ve Mısır Lirası olarak vergisi, ithalat ve ihracat farkı, gelirler, masraflar gösterilmektedir.

Arazi ile ilgili olarak (Mısr-ı Süflâ'daki (Kalyûbiyye, Şarkiyye, Dakahliye, Ğarbiyye, Menûfiyye ve Buheyra), Mısr-ı Ulyâ'daki (Cîze, Feyyûm, Benî Suveyf, Minye, Asyut, Circâ, Kinâ ve Vâdi-i Halfâ) ve Savakin, Arîş, Suveyş, Kanal, Port Said, Reşîd, İskenderiye ve Mısır (Kahire) Muhafızlıklarının ziraata uygun arazisi, nüfusları, ziraata uygun olmayan arazisi, fidanları, ziraata uygun olmayan araziden her yüz fidana isabet eden kişi sayısı, öşrü, fidan haracı ve fidan öşrü gibi bir çok hususu veren cedvel, muhafızlık ve müdüriyetlerden tahsil edilen vergi, toplam nüfus ve toplam varidat cedveli ile ziraata uygun olan arazi ile uygun olmayan arazi miktarma yer verilmektedir.

Ziraat başhı̆ında ekilebilir arazinin genel miktarı, mevsime göre arazinin idaresi ve kullanımı, muhtelif ekinlerin ekildiği arazilerin ölçümleri ve bunların toplamı, iki mevsimde Mısr-1 Süflâ ve Ulyâ'daki ziraat (Nîlî ziraat ve Sayfî ziraat) miktan, Mısr-1 Süflâ ve Ulyâ'da üç mevsim ziraatın hulasa cetvelleri, meyveli ağaçların ve bağların miktarı, ziraatte kullanılan ve demirbaş hayvanların miktan, 1887 yılı ziraatçe-i fihrist cetveli gibi birçok cetvel eklenmiştir.

Maarif başlıklı kısımda müellif Eski Mısır'dan Mehmed Ali Paşa dönemine kadar Mısır'ın eğitim tarihine kısa bir bakış sunduktan sonra Ezher ve Tanta Medreselerini zikretmekte müteakiben de bölgedeki mekteplerden mînî, evkâf ve ehlî isimleriyle anılan okullardan bahsetmektedir. Evkâf ve ehlî mektepleri doğrudan eğitim bakanlığının idaresi altında olup Küttâb denilen mahalle mektepleri ise bakanlığın teftişinde eğitim vermektedir. Burada mekteplerin isimleri, sınıfları, öğrenci sayısı, cinsiyeti, öğrencilerin hangi dine mensup olduklarına dair cetveller konulmuştur. Yine bu kısımda günlük, haftalık ve aylık olarak Mısır'da çıkarılan siyasî ve fennî evrâk-ı 
havâdislerin neşredildikleri lisan ile aylık ve günlük sürümlerinin sayısını açıklayan cetveller bulunmaktadır.

Demiryolları bahsinde müellif, Abbas Paşa zamanında ilk olarak Kahire ve İskenderiye arasına çekilen demiryolu hatının Mısır demiryollarının ilk hattı olduğunu müteakiben ülkenin her tarafına yayıldığını ve resmî kaynaklara göre ülke dâhilinde toplam 1750 kilometrelik demiryolu hattının varlığına değinmektedir. Bu hattın güzergahını gösteren iki adet de cetvel yer almaktadır.

Telgraf hatlar ile ilgili olarak yazar, zamanında Misır ile Hartum arasında bir telgraf hattının olduğunu söylemekte fakat sonradan meydana gelen olaylar neticesinde bu hattın kesildiğini ve tren hattının bulunduğu mevkilerin tümünde telgraf hattının mevcut olduğunu $(9526 \mathrm{~km})$ ifade etmektedir.

Posta için de yabancı ülkelere dahi Mısır'ın her yerinden (çoğunlukla geçiş yerlerinde ve uygun noktalara konulmuş kutulardan) yirmi dört saat zarfında altı kere dağıtıcıların elleri sürülmeksizin (kilitli torbalarla) muhtelif merkezlere ulaştırılan posta işlemlerinin olduğundan ve bunun kolaylığından bahsedilmektedir.

Lâhika-i Mebhas kısmında (s. 304-371) ise müellif, Mehmed Ali Paşa'dan başlayarak 1889 yılına kadar Osmanlı Mısır Sudanı'nda sürdürülen askeri faaliyetler üzerinde durmaktadır. Müellif bu seferler sonrasında Mısır Sudanı'nın sınırlarının Kongo hükümeti sınırlarının elli kilometre mesafesine kadar geldiğinden bahisle diğer taraftan da idarecilerin Uganda'nın ilhakı üzerinde faaliyet içerisinde olduklarını belirtmektedir. Yine bu kısımda kendisinin Mehdi olduğunu iddia ederek isyan eden Mehmed Ahmed isimli bir şahsın devlete karşı yürüttüğü askerî faaliyetleri uzun uzadıya anlatılmaktadır. Siyasî tarih sonrasında Sudan'ın müdüriyetlerinden (Dungula, Berbera, Hartum, Sinnâr, Feşûda, Feyzoğlu, Tâkâ, Kurdufân, Dârfûr) dokuz müdüriyetin coğrafî konumları, sınırları, şehirleri, nüfuslan, ürünleri, köyleri, yolları ve bu müdüriyetlerin kısa tarihi bilgilerine yer verilmiştir. Burada müellif Mehmed Ali Paşa'nın Sudan'a vermiş olduğu öneme dikkat çekerek sonrakilerin buraya ilgisizliklerine değinmekte ve bu idarecilerin buraya gönderdiği asken̂ keşif birliklerinde sık sık Avrupalı subayları komuta düzeyinde görevlendirdiklerini (Mesela Gordon Paşa) ve bu şahısların daha çok kendi hükümetlerine hizmet ettiklerini belirtmektedir (s. 347). Bu keşif gezilerinde buralarda oluşturulmuş olan köle pazarlarının da dağıtıldığından bahsedilmektedir.

Tetimme kısmı Mısır Tarihi başlığı altında olup müellif bunu da Akdemîn (Eski Mısır) ve Müteahhirîn diye iki kısımda ele almıştır. Akdemîn 
kısmında Eski Mısır'ın dinî yapısının üç devre hâlinde taksim edildiğinden başlayarak Eski Mısır'da hüküm süren toplam otuz dört aileyi ele almakta bu kısım sonrasında da Eski Misır eserlerini ve bu eserlerin bir kısım plan ve resimlerine yer vermektedir (s. 372-480).

İkinci kısım (müteahhirin)da Amr b. el-As'ın Misır'ı fethini konu edinmiş ve burada (m. 640) Ferma, Bülbeys, Kasru'ş-Şem' (Babilyon)'un fethini ve Mukavkıs'la yapılan antlaşmaya müteakiben de Iskenderiye, Dimyât, Tinnîs, Berellüs'ün ele geçirilmesine ve Nil'i Kızıldeniz'e bağlayan eski kanalın açılması, Bingâzi ve Berberiyye'nin fethi, İskenderiye'ye yapılan saldırının püskürtülmesi, Hz. Osman devri, Abdullah b. Ebî Serh'in valiliği, Hz. Ali'nin hilafetinde Kays b. Sa'd ve Muhammed b. Ebî Bekr'in valilikleri, Amr b. el-As'ın ikinci defa valiliğgi, Emevîler ve Abbasîler devrinde meydana gelen olaylar, Tolunoğlu Ahmed'in ortaya çıkışı, el-Asker ve Katâi' şehirlerinin tesisi, Fatimîler devletinin iktidan ele geçirmeleri, Haçlı saldırılarına, Selahaddin Eyyûbî'nin zuhuru, bağımsızlığını ilan etmesi, hükümranlığına ve Haçlllarla mücadelesine sonra da Eyyübîler devletinin çöküşü ve Bahrî Memlüklerin idareyi ele geçirmelerine yer vermektedir. Abbasi Halifesi'nin Bağdad'dan Mısır'a kaçışı ve sonrasında cereyan eden birçok olay ve bunların kahramanlan hakkındaki bilgiler burada zikredilmektedir. Bahrî Memlükler sonrasında Çerkes Memlüklerinin saltanatlarından bahisle bu devletin hükümdarları ve bu dönemde cereyan eden önemli olaylar konu edilmektedir. Eserin elimizdeki nüshaya göre birinci cildi, Yavuz Sultan Selim'in Merc-i Dâbık ve Ridâniye zaferleriyle Kahire'nin Osmanlı hâkimiyetine girişinden başlayarak Mısır'da Osmanlı idaresisinin tesisi ile 1213/1898'e kadar burada görev yapan valiler ve cereyan eden olayların ele alınması ile son bulmuştur (s. 475-769). Müellif Napolyon'un Mısır'ı işgaliyle birlikte icra ettiği siyasî faaliyetlerini ikinci ciltte hazırlamayı düşündüğünü ifade ederek birinci cildi bitirmiştir (s. 769).

Eser sayfa sayısı (769s.) ve büyük boy olması itibariyle hacim olarak çok geniş tutulmuş, içerisine çok sayıda fotoğraf ve üç adet de harita (Orta Afrika, Habeşistan- Sudan ve 1/300.000 ölçekli Hidiviyyet-i Celîle ve Sudân-1 Mısr-1 Osmanî haritaları) yerleştirilmiştir.

Müellif eserinde tarih ve coğrafya kitapları, atlaslar, sevkiyat kayıtlan, (özellikle Sudan'da görev yapan eski memurların) sözlü anlatımlan gibi çeşitli ve çok sayıda kaynak kullanmış olup bunların isimlerini giriş kısmında zikretmiştir. Yazar ayrıca Mısır'da görevli olarak bulunduğundan çalışmasında kendi gözlemlerine de yer vermiştir. Kitapta dipnot kullanımı da yapılmış ve özellikle de Mebhas kısmında Mısır'daki idarî birimler, 
köyler ve kasabalar anlatılırken, yer yer bunlardan önemli olanlarının tarihî ve coğrafî̀ bir kısım özellikleri dipnotlarda verilmiş, bu yerleşim merkezlerinde varsa Eski Mısır'ın arkeolojik varlığından da bahsedilmiştir. Bunlara ek olarak da anlatılan konular yine sayfa içerisinde sayısal bilgiler ve şemalar ile desteklenmiştir. Bu kadar büyük ve hacimli bir eser de tabii olarak birçok yanlışıkların (özellikle basıldığı dönem itibariyle) bulunması söz konusu olacağından kitabın başına yedi sayfalık doğru yanlış cetveli de konulmuştur.

Sonuç olarak Afrika Delili başlı̆̆ı altında yazılan bu eser medhal kısmında verilen yüz küsur sayfa ve Sudan hakkındaki bilgiler (s.304-371) hâriç tutulacak olursa büyük kısmı Mısır'ın tarihi, coğrafyası, idarî bölümleri, iklimi, ürünleri gibi konuları işleyen bir eserdir. Eski Mısır ve yazıldı̆̆ı döneme kadar Mısır'ın tarihi hakkında zengin bilgileri ihtiva eden bu çalışma Mısır (ve özelde Sudan'ın) tarihi ve coğrafyası hakkında telif edilmiş eserlerden birisi olması açısından ve ayrıca Hidivlik dönemi ile ilgili bilgilere yer vermesi ve yazarın kendi gözlemlerini de içermesi bakımından Mısır hakkında (özellikle yakın tarih) araştırma yapacaklar için çok önemli bir yere sahiptir. Bütün bu özellikleri ve Türkçe kaleme alınmış olması itibariyle Afrika Delili isimli bu kitap araştırmacılar için değerli bir kaynak hüviyetini taşımaktadır. 